\title{
Penta Helix Synergy in Halal Tourism Development
}

\author{
Sri Umiyati ${ }^{1}$ M. Husni Tamrin ${ }^{2, *}$ \\ ${ }^{1}$ Department of Public Administration, Universitas Hang Tuah \\ ${ }^{2}$ Department of Public Administration, Universitas Hang Tuah \\ *.Email: m.husnitamrin@hangtuah.ac.id
}

\begin{abstract}
The development of halal tourism recently becomes the global market phase. It is important necessity for developing halal tourism destinations for Moslem travelers. Since 2019, the Global Muslim Travel Index (GMTI) has planned that the number of Moslem travelers in the world are predicted to increase in the following year. This study aims to find out the development of halal tourism in Malang district which is observed from the perspective of Penta Helix stakeholder synergy element, such as the academics, business actors, community, government, and the media. The method used in this analysis is qualitative descriptive and the data collection techniques conducted by direct observation, interviews, and documentation. The results show that the lack of optimal halal tourism as the largest contributor to foreign exchange and economic acceleration is due to lack of coordination and synergy among various stakeholders. As the result, the management of halal tourism, coordination and collaboration between the government, business actors, communities, academics, and the media are included in Penta Helix element.
\end{abstract}

Keywords: Halal Tourism, Penta Helix, Synergy

\section{INTRODUCTION}

The development of halal tourism is one of important factor in the economic growth. In fact, the number of Moslem travelers is estimated around 158 million people in 2020 (katadata.co.id, 2020). Furthermore, there are 230 million Moslem travelers in 2026. The interpretation of halal tourism requires certain consideration regarding the classification of Moslem travelers whose numbers are increasing each year. Crescent Rating has mentioned several development goals of halal tourism which include important values for halal tourism development. The development goals pay attention both economic and socio-cultural factors as well as the spiritual factor on halal tourism trips.

According to Global Muslim Travel Index (GMTI) data in 2019, this tourism type was categorized as halal if it had ecosystem service-based religion, such as halal food, worship facilities, toilet room with ablution water, and a non-Islamophobic environment. The important point in halal tourism is how tourism can increase the comfort without neglecting the faith aspect and improve the understanding through historical and cultural heritage sites. Indonesia has the largest of Syariah economic market and the awareness of halal tourism potential. This country has prepared Syariah economic masterplans for the year 2019 to 2024 which are developed by Bappenas.
This tourism-based religion hopefully can support the service trade balance and have an impact for another sectors, including aviation, hospitality, and culinary businesses. Governor deputy of Bank Indonesia, Dody Budi Waluyo, states that Indonesia and Malaysia are currently at the top rank for the best halal tourism destinations. The number of global Moslem tourism reached 140 million people last year with a spending value of US \$35 billion. The development of halal tourism is in accordance with the government's commitment to encourage the economic growth in Indonesia.

In general, Indonesia has had ten leading tourism destinations since 2018. The ministry of tourism and creative economy cooperates with GMTI in order to develop ten Moslem tourism destinations in Indonesia, such as Aceh, West Sumatera, Riau and the islands of Riau, DKI Jakarta, West Java, Central Java, Yogyakarta, East Java, Nusa Tenggara Barat (NTB), and South Sulawesi. Indonesia is rich in cultural and biological diversities, as well as values for tourism development. The Moslem travelers are increasing every year and the growth of Moslem middle-class income can be as the golden potential in Indonesia. The trend of public awareness in adopting halal lifestyle is also a great opportunity for Moslem tourism to develop rapidly in Indonesia. The ministry of national development 
planning agency or head of Bappenas Year 2014-2019 states that Indonesia would encourage the strategy arrangement of halal tourism by strengthening the integration of tourism packages, improving human resources quality, and providing regulatory supports, as well as technological facility. The issue of halal tourism regulation is also mentioned in Syariah economic masterplan Year 2019-2024. Anang Sutono as the expert staff of the Ministry of Tourism and Creative Economy states that he arranges the strategy of halal tourism industry development in Indonesia. The development of halal tourism is conducted in order to provide the comfortable place to worship for Moslem travelers, but it's not a restriction for non-Moslem visitors.

The high potential of halal tourism market can be seen from the increasing number of the travelers. According to the data of Global Muslim Travel Index (GMTI), it shows the number of Moslem travelers reaching 158 million people in 2020. The number is growing $21 \%$ compared to the number of the travelers in 2017. This number excludes the activities of pilgrimage and umrah tour.

Table 1. World Halal Tourism Destination Countries

\begin{tabular}{|c|c|c|}
\hline OKI Members* & Rating & Non-Member \\
\hline Malaysia & 1 & Singapore \\
\hline Indonesia & 2 & Thailand \\
\hline $\begin{array}{c}\text { United of Arab } \\
\text { Emirates }\end{array}$ & 3 & England \\
\hline Turkey & 4 & Japan \\
\hline Saudi Arabia & 5 & Taiwan \\
\hline Qatar & 6 & Hong Kong \\
\hline
\end{tabular}

Table 2. Ranking Data of Indonesia Moslem Travel Index (IMTI) in 2019

\begin{tabular}{|l|l|}
\hline $\begin{array}{l}\text { The Top } 5 \text { of Halal Tourism } \\
\text { Destinantion }\end{array}$ & $\begin{array}{r}\text { The Leading Halal Tourism } \\
\text { Destination }\end{array}$ \\
\hline 1. Lombok, NTB & 6. West Java \\
\hline 2. Aceh & 7. Yogyakarta \\
\hline 3. Riau and the islands of Riau & 8. Central Java \\
\hline 4. DKI Jakarta & 9. Malang-East Java \\
\hline 5. West Sumatera & 10. South Sulawesi \\
\hline Source: Crescent Rating-Mastercard &
\end{tabular}

The high numbers of travelers had an impact on tourism spending, starting from plane tickets purchasing, hostelry, and another accommodation which reached US $\$ 177$ billion or Rp. 2.500 trillion in 2017. This number is estimated to increase up to US $\$ 300$ billion or Rp. 4.200 trillion in 2026. The potential of halal tourism is also being observed by non-Moslem countries, such as
Singapore, Thailand, Britain and Japan. These countries have prepared the number of comfort facilities for Moslem tourists, especially in the ease of obtaining halal food and the five daily prayers. In addition, toilet facilities are also repaired with water-based equipment.

Table 2. shows that Indonesia obtained the first rank internationally as a world halal tourism destination according to Global Moslem Travel Index (GMTI) in 2019. The growth of Indonesian halal tourism reached $18 \%$ in 2018. The number of foreign Moslem tourists visited halal tourism destinations in Indonesia reaching up to 2.8 million with the foreign exchange reaching more than 40 trillion. As the result, the Ministry of Tourism and Creative Economy took the opportunity by following up the development of top 10 halal tourism destinations as the national priority according to GMTI standards.

The government's strategy in developing tourism is the collaboration of Penta helix Model. This model was first initiated by the Ministry of Tourism and Creative Economy, Arief Yahya, which was stated in the Ministerial Regulation Number 14 Year 2016 concerning the guidelines for sustainable tourism destinations. In order to create orchestration and ensure the quality of activities, facilities, services, and to create experiences and the benefits of tourism, society and the environment, it is necessary to encourage the tourism system through optimizing the roles of business actors, government, community, academics, and the media (BGCAM).

This research is conducted in order to observe the synergy of Penta Helix in the effort of increasing halal tourism potential in Malang- East Java. The result provides a solution strategy in the collaboration of Penta Helix model in developing halal tourism in Malang-East Java, so that it can support the domestic economy.

\section{THEORETICAL FRAMEWORK}

\subsection{The Penta Helix synergy}

The interaction between five stakeholders requires synergy among them. Najiyati and Rahmat (2011) define synergy as a combination or collaboration that provides better and greater output [1]. So, synergy is defined as the combination of some elements to obtain better output. Synergy can be obtained in two ways, they are.

\subsubsection{Communication}

Define Sofyandi and Garniwa in Rahmawati, et al (2014) explain the definition of communication that can be divided into two parts [2]:

1. The definition of source-oriented communication. Communication is an activity in which a person (source) actually moves stimuli in order to get a response. 
2. The definition of recipient-oriented communication. Communication is all activities in which a person (receiver) responds to a stimulus.

\subsubsection{Coordination}

Use Coordination is also required in order to create synergy. Communication can't stand alone without coordination. In line with this, Hasan (2005) states that communication requires coordination. Silalahi (2011) states that coordination is the integration of individual activities and units into one effort, namely working towards a common goal [3].

Moekijat in Rahmawati et.al (2014) states that there are nine requirements in order to achieve effective coordination, namely [2]:

1. Direct relationship. Coordination can be easily achieved through direct personal relationships.

2. Initial opportunities. Coordination can be achieved easily at the beginning phase of planning and policy making.

3. Continuity. Coordination is a continuous process and must take place at all times starting from the planning stage.

4. Dynamic coordination. Coordination must be continuously changed in view of changes in the environment internally and externally.

5. Obvious objectives. These objectives are important for effective coordination.

6. Simple organization. Simple organizational structure facilitates effective coordination.

7. Obvious formulation of authority and responsibilities. Obvious authority does not only reduce conflicts between different employees, but also help them to work in a unified purpose.

8. Effective communication. Effective communication is one of the requirements for good coordination.

\subsection{Penta Helix synergy in Tourism Development}

The government's attention in the efforts of developing tourism sector in Indonesia can be seen in the recognition of tourism sector as one of economic pillars. The most important phase in increasing the foreign exchange is enhancing the regional income and absorbing investment, as well as reducing unemployment by providing job vacancies. However, tourism development can't only depend on the government because many parties are involved. Therefore, it is compulsory to have the synergy in the management of tourism industry. Jahid (2019) states that the history of development in synergy concept of tourism development is initiated by the triplehelix idea adopted from Etzkowitz \& Leydesdorff's theory in 2000. The triple-helix concept emphasizes the relationship between universities, industry and government [4] [5]. In 2014, Lindberg developed a new concept called the quadruple helix by adding some elements of local society to complement the triple-helix concept that had already developed. On the other hand, Penta helix concept was proposed by Riyanto in 2018 in

Table 4. Rethinking Stakeholders' Helixes-Strategies

\begin{tabular}{|c|c|c|c|}
\hline & $\begin{array}{c}\text { Triple Helix } \\
\text { (TH) }\end{array}$ & $\begin{array}{l}\text { Quadruple } \\
\text { Helix (QH) }\end{array}$ & \begin{tabular}{|c}
$\begin{array}{c}\text { Penta Helix } \\
(\mathrm{PH})\end{array}$ \\
\end{tabular} \\
\hline Literature & $\begin{array}{l}\text { Etzkowithz } \\
\text { and } \\
\text { Leydesdorff } \\
(2000)\end{array}$ & $\begin{array}{l}\text { Goddard } \\
(2016)\end{array}$ & $\begin{array}{l}\text { Ostrom (2010) } \\
\text { Anttiroka } \\
(2016) \\
\text { Calzada } \\
\text { (2017) } \\
\text { Riyanto in } \\
\text { Rizkiyah } \\
(2018) \\
\end{array}$ \\
\hline $\begin{array}{l}\text { Multi- } \\
\text { Stakeholders }\end{array}$ & $\begin{array}{l}\text { Public } \\
\text { Private } \\
\text { Academia }\end{array}$ & $\begin{array}{l}\text { Public } \\
\text { Private } \\
\text { Academia } \\
\text { Civic Society }\end{array}$ & $\begin{array}{l}\text { Public } \\
\text { Private } \\
\text { Academia } \\
\text { Assemblers: } \\
\text { (Social) } \\
\text { Entrepreneurs } \\
\text { or/and } \\
\text { Activists } \\
\text { Media } \\
\end{array}$ \\
\hline Paradigms & $\begin{array}{l}\text { Public } \\
\text { Private } \\
\text { Partnership }\end{array}$ & $\begin{array}{l}\text { Civic } \\
\text { Universities }\end{array}$ & $\begin{array}{l}\text { Urban } \\
\text { Commons }\end{array}$ \\
\hline $\begin{array}{l}\text { Governance } \\
\text { Scheme and } \\
\text { Citizenship } \\
\text { Response }\end{array}$ & $\begin{array}{l}\text { Inversible } \\
\text { Citizenship }\end{array}$ & $\begin{array}{l}\text { Reactive } \\
\text { Citizenship }\end{array}$ & $\begin{array}{l}\text { Proactive } \\
\text { Citizenship }\end{array}$ \\
\hline $\begin{array}{l}\text { Techno- } \\
\text { Politics of } \\
\text { Data }\end{array}$ & $\begin{array}{l}\text { Technocratic } \\
\text { Top-Down }\end{array}$ & $\begin{array}{l}\text { Institutionalized } \\
\text { Bottom-Up }\end{array}$ & $\begin{array}{l}\text { Emergent and } \\
\text { Complex } \\
\text { Bottom-Up } \\
\end{array}$ \\
\hline \multicolumn{4}{|c|}{$\begin{array}{l}\text { Sources: researcher analysis* } \\
\text { *) Concept modification in Igor Calzada (2016). "Beyond Smart and Data-Driven } \\
\text { City-Regions? Re-thinking Stakeholder-Helixes Strategies" and Putri Rizkiyah. } \\
\text { Et.al (2019) "The Synergy of Penta helix in tourism recovery after eruption disaster } \\
\text { of Sinabung in Karo district, North Sumatera." }\end{array}$} \\
\hline
\end{tabular}

which included the media that played significant role in developing social capital for development.

\section{RESEARCH METHODS}

In this study, the authors apply a qualitative descriptive method that creates a systematic, factual and accurate description of the facts and characteristics of a particular population that is used as the subject of research. The description proves that halal tourism development can be observed.

Furthermore, the analysis is conducted according to the research problems and the elaboration of the data collection by referring to the relevant theoretical framework. As the result, the study provides systematic, factual, and accurate description in developing halal tourism in terms of the stakeholders' synergy sustainably. 


\section{RESULT AND DISCUSSION}

\subsection{The synergy of Penta Helix in halal tourism development in Malang district}

In 2018, the Mayor of Malang district, Drs. Sutiaji declared that Malang district would become halal tourism destination by applying the concept of halal, safe and healthy. The enthusiasm of entrepreneurs in realizing halal tourism destinations should be appreciated because entrepreneurs of hospitality, restaurants and entertainment have registered for halal certification.

The development of halal tourism will be realized by communication and coordination as well as the role of stakeholders, including governments, universities, community, business actors and the active role of media, so that the synergy of the Penta Helix is applied.

The government of Malang district and the Rectors forum who are represented by the Rector of Universitas Brawijaya have signed Memorandum of Understanding/MoU with the ministry of tourism and creative economy as the initial step to develop halal tourism in Malang district. The MoU contains the agreement and understanding regarding the development of halal tourism by preparing not only accommodation but also various facilities that can be utilized by the visitors. The $\mathrm{MoU}$ is also aimed to develop human resources in tourism sector, the regulation and the governance, and the universities' assistance.

The MoU obtains the design of halal tourism plan and strategy. The government's commitment for the development of halal tourism is proven by the declaration of vision and mission of the Mayor: "Future of Malang." The declaration contains "halal Malang." For this reason, it requires reinforcement in the implementation of halal tourism plan and strategy designs by using stakeholder synergy. The stakeholders are the academics who represented by the halal centre, the government of Malang district, business actors, local community, and mass media in Malang district.

Because of the demand in halal assurance for both food and beverages, the implementation of DSRA is conducted by providing human resources training on halal products and halal legality certification for both restaurants and hotels. According to the law Number 33 Year 2014 and the government regulation Number 31 Year 2019 regarding halal product guarantees, the obligation of halal products for food and beverages in restaurants and hotels must be certified by LPPOM MUI. As the result, the department of youth, sports, and tourism in Malang district facilitates halal certificates for restaurants and hotels in this city. The government of Malang district and halal centre in five universities cooperates with LPPOM MUI and the accelerated team of halal tourism in order to hold technical guidance for halal assurance system with the principle of halal, safe, and healthy.

\subsection{The Role of Stakeholders in Penta Helix Model}

Stakeholders in Penta Helix Model aim to find out the roles of stakeholders in the development program of halal tourism in Malang-East Java. The analysis of the role of stakeholders in Penta Helix model as follows.

\subsubsection{Academics}

Define Academics in Penta Helix model acts as the conceivers, such as standardizing business process, certification of halal products, as well as human resources skills. The academics are the source of knowledge, concepts, new and relevant theories in the process of mentoring and managing halal certification. Halal Centre in Malang district consists of several universities, such as Universitas Brawijaya, Universitas Negeri Malang, Universitas Muhammadiyah Malang, Universitas Islam Malang, and Universitas Islam Negeri Maulana Malik Ibrahim Malang in collaboration with LPPOM MUI and accelerated team of halal tourism development (TP3H). The collaboration is aimed to hold technical guidance for halal assurance system with the principle of halal, safe, and healthy. The halal certificates will be officially issued by BPJPH in the ministry of religious affairs after a series of audit processes. It is known that BPJPH is the only organization who has the authority to publish and deprive halal certification. This has been stipulated in the law Number 33 Year 2014 regarding halal product guarantees. It is clearly written that BPJPH has the absolute authority of halal products certification.

\subsubsection{Business actors}

Business people on Penta Helix model act as the enablers. Business is an entity that does business processes in creating additional value and maintaining sustainable growth, especially in halal tourism. Nowadays, halal tourism in Malang district that has obtained the legality of halal certification is Swiss-Bellin hotel. However, halal tourism bazaar that provides potential amenities and halal tourism destinations, such as, 1) Regent Hotel, Guest House Universitas Brawijaya, Ubud Hotel, Atria Hotel, dan Savana Hotel, 2) Inggil restaurants, Taman Indise restaurants, Wansho Restaurants China Halal, Food Court Halal Toyib Universitas Brawijaya, 3) Travel Tombo Ati, Travel AsSalam, Trans studio Mini, Jatim Park Group, Hawai Group (Ganesya Museum, dan Malang Night Paradise), 5) Dinoyo Shopping Mall, Klojen market, Oro-oro Dowo market, Bunulrejo market, 6) Oleh-oleh Malang Strudel, Lapis Malang, Bolu Singosari, and various halal products by Halal Center. 


\subsubsection{Community}

The community on Penta Helix model acts as the accelerator. It means that the community is the group of people who have the same interests and act in the growing business. They also act as the intermediary between stakeholders in order to assist business actors in the whole process, and facilitate the implementation of halal certification according to the vision and mission of the government in Malang district.

The community that supports halal tourism is Indonesian Hotel and Restaurant Association (PHRI). A support for hotel is started with basic accommodations that provide facilities for Moslem to worship. The facilities are a place for ablution in a hotel room, prayer equipment, Al-Qur'an, Qibla pointer, and a prayer room. Besides that, prayer schedule information is also a basic necessity which can't be neglected. The reason is that foreign tourists need time adjustments while domestic tourists sometimes do not know the prayer times between western, central and eastern Indonesia.

In addition, every food served should be certified halal in all restaurants. The existence of a government policy for halal certification is considered to be appropriate and in accordance with the needs of tourism industry. Furthermore, Yusran explains that travel agents must support the halal tourism necessity, such as providing schedule to pray, so that the people can worship comfortably while they are traveling.

The development process of halal tourism is still a polemic in the community. Halal tourism is interpreted as an effort to justify the destinations and ignore other religions. According to Vice President's instructions, the concept is the extended services for Moslem tourists.

There was rejection from cultural observers and artists in the development of halal tourism because they were considered too exclusive. This was also conveyed by academic informants who conducted research on the acceptance of halal tourism label in Malang. There was $30 \%$ rejection from cultural observers, especially those who had established Malang to be an icon of tolerance among youth. They do not want the justification for halal label which is the privilege of a religion or culture.

\subsubsection{Government}

The role of government in Penta Helix model is as the regulator. The government acts as a regulator as well as a facilitator who has regulations and responsibilities in developing halal tourism. In this case, it involves all types of activities such as planning, implementation, monitoring, control, promotion, financial allocation, licensing, programs, legislation, development and knowledge.
The strengthening of halal tourism continues to be applied by the government of Malang district. One of the efforts is the workshop on strengthening halal tourism with the theme of creating Malang as a leading halal tourism destination. The activity which initiated by the department of youth, sports and tourism was held in Sahid Montana Hotel on Monday, February 11, 2020. The mayor of Malang district, H. Sutiaji emphasized that halal Malang which was currently one of the centres of tourism, expected to be easier for tourists to find halal places in Malang city.

H. Sutiaji also explained that there were many components of halal tourism destinations and the values must be supportive. If the hotel and restaurants were certified, the tourists would be easier to find these facilities. One of the examples was Japan which had halal tourisms and it's easy to get them.

The Head of youth, sports, and tourism department, Ida Ayu Made Wahyuni said that twenty businesses were strived for halal certification even though they were facilitated by the government. She admitted that it was a necessity to increase the requirements for halal certification.

The head of youth, sports, and tourism department also explained that there was another specified requirement had not been fulfilled, for example the certification for halal kitchen. One ingredient like sauce should also be certified. If it wasn't certified, there must be the substitute product. This obstacle became the problem for hotels and restaurants to get halal certification.

Some efforts have been applied by the government as the strategy in supporting the development of halal tourism in Malang. The government not only acts as the coordinator, but also tries to develop halal tourism in Malang. The development includes holding Malang culinary bazaar in the city hall, seminars and technical guidance for the preparation of halal certification applications for Small Medium Enterprises (SME). The programs aim to increase awareness of halal certification and they are held in five universities in Malang, and five locations as halal pilot project.

The result of interview with the key stakeholders shows that halal context is not only based on the value of appearances, like the place and the clothes, but also how food is actually served in halal standard. The standard for the food is how to slaughter animals properly and correctly.

In addition, the government of Malang city also acts as the catalyst. The government must consider that all factors can influence the development of halal tourism. Moreover, they also control the negative factors that tend to be obstacles, so that their impacts can be minimized. The government also identify the factors that encourage the development of halal tourism so that the tourism can 
Table 5. The analysis of the roles and duties of Penta Helix stakeholders in the development of halal tourism in Malang

\begin{tabular}{|c|c|c|c|}
\hline Stakeholders & $\begin{array}{c}\text { The } \\
\text { Implement } \\
\text { ers }\end{array}$ & Roles & Definitions of role \\
\hline Academics & $\begin{array}{c}\text { Halal Centre } \\
\text { in Higher } \\
\text { Education/ } \\
\text { Universities }\end{array}$ & Conceiver & $\begin{array}{l}\text { - To identify the } \\
\text { potential and } \\
\text { certification of a } \\
\text { product, as well as } \\
\text { the human } \\
\text { resources skills that } \\
\text { support halal tourism } \\
\text { potency. } \\
\text { - To obtain the } \\
\text { source of knowledge } \\
\text { concerning the } \\
\text { concept and new } \\
\text { theories of potential } \\
\text { development. }\end{array}$ \\
\hline Business actors & \begin{tabular}{|c|} 
Small \\
Business \\
Enterprises \\
(SME), hotel \\
and \\
restaurant \\
entrepreneu \\
rs
\end{tabular} & Enabler & $\begin{array}{l}\text { - To do business } \\
\text { process for creating } \\
\text { additional values } \\
\text { and maintain the } \\
\text { sustainable growth } \\
\text { of halal certification. }\end{array}$ \\
\hline Community & $\begin{array}{c}\text { Indonesian } \\
\text { Hotel and } \\
\text { restaurant } \\
\text { Association } \\
\text { (PHRI) }\end{array}$ & Accelerator & $\begin{array}{l}\text { - To have similar } \\
\text { and relevant interest } \\
\text { by improving the } \\
\text { growing potency. } \\
\text { - To be intermediary } \\
\text { or mediator among } \\
\text { the business actors } \\
\text { and the government } \\
\text { in the whole } \\
\text { process. } \\
\text { - To accelerate the } \\
\text { adoption of } \\
\text { economic process in } \\
\text { supporting halal } \\
\text { tourism. }\end{array}$ \\
\hline Government & $\begin{array}{l}\text { (The } \\
\text { government } \\
\text { of Malang } \\
\text { district and } \\
\text { the ministry } \\
\text { of tourism } \\
\text { and creative } \\
\text { economy) }\end{array}$ & $\begin{array}{l}\text { Regulator } \\
\text { and } \\
\text { Controller }\end{array}$ & $\begin{array}{l}\text { - To have } \\
\text { regulations and } \\
\text { responsibilities in } \\
\text { developing tourism } \\
\text { in term of the } \\
\text { implementation, } \\
\text { monitoring, } \\
\text { controlling, } \\
\text { promotion, financial } \\
\text { allocation, license, } \\
\text { program, and the } \\
\text { coordinator of } \\
\text { stakeholders. }\end{array}$ \\
\hline Media & $\begin{array}{l}\text { Radio City } \\
\text { Guide } 911 \\
\text { FM }\end{array}$ & Expander & $\begin{array}{l}\text { - To support } \\
\text { publication in } \\
\text { promotion } \\
\text { - To make the brand } \\
\text { image of halal } \\
\text { tourism. }\end{array}$ \\
\hline \multicolumn{4}{|c|}{$\begin{array}{l}\text { Sources: researcher analysis (2020) } \\
\text { *) Concept modification in Etzkowitz \& Leydesdorff (2017) “The dynamics of innovation: } \\
\text { from National Systems and 'Mode 2' to a Triple Helix of university-industry-government } \\
\text { relations." and Jamaludin Jahid (2019) "Tourism Destinations: Need Synergy and the } \\
\text { Role of Penta Helix." }\end{array}$} \\
\hline
\end{tabular}

get more benefits. The dynamist role means that the government should provide directions for stakeholders regarding the development of halal tourism in Malang.

\subsubsection{Media}

The role of media in Penta Helix model acts as the expender. The media plays a role in supporting publication in promotion and creating a brand image for halal tourism. One of the media used as the promotion for development program of halal tourism is Radio City Guide 911 FM. The programs are about the information distribution on tourism spots with the product of Jalan Plus as well as 911 Hot News Program. The function of this media will encourage people to visit halal tourism sites by introducing halal tourism in Idjen Talk program, offering tips and solutions for traveling in halal tourism spots, and involving listeners through WhatsApp messages.

\section{CONCLUSION}

Halal tourism is a potential sector that should be explored because of the increase in halal tourism market that can be seen from the increased number of the travellers. The data taken from Global Moslem Travel Index (GMTI) shows that moslem travellers are estimated 158 million in 2020 . The number is increasing up to $21 \%$ compared to the number of the travellers in 2017. The number is not the total of pilgrimage and umrah activities. For this reason, the development of halal tourism in Malang city needs mutual commitment and the stakeholders' synergy in Penta Helix (the government, business actors, community, academics, and the media that have important roles). Based on the analysis, it can be concluded that Penta Helix synergy is the accurate strategy in developing halal tourism in Malang to be the Future of Malang or Halal Malang. Several programs are not optimal if one of the parties do not play the roles maximally. So, it requires a solid collaboration.

\section{REFERENCES}

[1] Najiyati, Sri dan S.R. Topo Susilo. Sinergitas Instansi Pemerintah Dalam Pembangunan Kota Terpadu Mandiri (The Synergy of Goverment Institutions in The Transmigration Urban Development). Jurnal Ketransmigrasian [Internet], 28 (2) Desember 2011, pp.113-124

[2] Rahmawati, Triana. Irwan Noor, dan Ike Wanusmawatie. Sinergitas Stakeholders dalam Inovasi Daerah (Studi pada Program Seminggu di Kota Probolinggo (SEMIPRO)). Malang: Jurnal Administrasi Publik Univeristas Brawijaya, 2014. Vol. 2, No. 4, pp. 641-647

[3] Silalahi, Ulbert. Asas-asas Manajemen. Bandung: Refika Aditama, 2011 
[4] Jahid, Jamaludin (2019) "Destinasi Wisata: Butuh Sinergi dan Peran Penta Helix", 2019. https://fajar.co.id/2019/06/17/destinasi-wisatabutuh-sinergi-dan-peran-penta-helix/2/

[5] Etzkowitz, H. and Leydesdorff, L. (2000). The dynamics of innovation: from National Systems and 'Mode 2' to a Triple Helix of universityindustry-government relations. Research Policy, 2000, Vol. 29.

[6] Igor Calzada (2016). "Beyond Smart And DataDriven City-Regions? Rethinking StakeholderHelixes Strategies" Regions The Voice of The Membership Regional Studies Association, Sussex Innovation Centre, Falmer, Brighton BN1 9SB, United Kingdom, 2016.

[7] G. Amrial, et.al (2017). Penta Helix Model: A Sustainable Development Solution Through The Industrial Sector. 2017. https://www.researchgate.net/publication/3211067 43
[8] Handy Ariwibowo (2018). Implementasi Kolaborasi Model Pentahelix Dalam Rangka Mengembangkan Potensi Pariwisata Di Jawa Timur Serta Meningkatkan Perekonomian Domestik. Surabaya: Jurnal Manajemen Ekonomi Bisnis, 2018, Vol 3 No 1

[9] Rizkiyah, Putri. Liyushiyana dan Herman. Sinergitas Pentahelix Dalam Pemulihan Pariwisata Pasca Bencana Erupsi Gunung Api Sinabung Di Kabupaten Karo, Sumatera Utara”. Universitas Udhayana: Jurnal Industri Perjalanan Wisata Vol. 07, 2019, No. 02 pp. 248.

[10] Soemaryani, Imas. Pentahelix Model To Increase Tourist Visit To Bandung And Its Surrounding Areas Through Huan Resource Development. Academy of Strategic Management Journal, 2016, Volume 15, Special Issues 3.

[11] Undang Undang No.33 Tahun 2014 tentang Jaminan Produk Halal (UU JPH) dan

[12] Peraturan Pemertintah No. 31 Tahun 2019 tentang Jaminan Produk Halal. 